\title{
Penggunaan Model Pembelajaran Discovery Learning untuk Meningkatkan Kemampuan Pemecahan Masalah pada Siswa SMP
}

\author{
Dede Eti Nurhasanah ${ }^{1}$, Nia Kania ${ }^{2}$, Aep Sunendar ${ }^{3}$ \\ Pendidikan Matematika, FKIP Universitas Majalengka \\ email: Dedeeti95@gmail.com
}

\begin{abstract}
Abstrak-Penelitian ini bertujuan untuk melihat pengaruh penggunaan model pembelajaran Discovery Learning terhadap kemampuan pemecahan masalah matematis siswa SMP. Penelitian ini merupakan penelitian eksperimen. Populasi dalam penelitian ini adalah siswa kelas VIII, sedangkan sampel nya adalah siswa kelas VIII A sebagai kelas eksperimen dan VIII B sebagai kelas kontrol di SMP Islam Abata Malausma. Penelitian ini menggunakan desain penelitian The Nonequivalen Pretes-Postes Control Group Design. Populasi dalam penelitian ini adalah seluruh siswa kelas VIII SMP Islam Abata Malausma, Kecamatan Malausma Kabupaten Majalengka tahun ajaran 2018/2019. Sementara sampel kelas VIII A sebagai kelas eksperimen dan VIII B sebagai kelas kontrol. Hasil Penelitian disimpulkan sebagai berikut: (1) Penggunaan model pembelajaran discovery learning dapat meningkatkan kemampuan pemecahan masalah matematis siswa SMP kelas VIII dengan sangat baik. Hal ini dibuktikan dengan nilai rata-rata di akhir pembelajaran sebesar 54 dari skor maksimal 80 yang pada awalnya hanya memiliki rata-rata 5,44 dari skor maksimal 80; (2) Aktivitas siswa ketika pembelajaran menggunakan model discovery learning dalam memecahkan masalah matematika sebesar $80 \%$ pada kategori baik. Hal ini dibuktikan dengan peningkatan aktivitas siswa ketika pembelajaran sebesar 4 dari nilai maksimal 5 dan hal itu termasuk dalam kategori baik.
\end{abstract}

\section{Kata kunci: Discovery Learning, Pemecahan Masalah Matematis, Siswa SMP}




\section{PENDAHULUAN}

Matematika merupakan salah satu mata pelajaran yang memiliki jam terbanyak untuk dipelajari dalam kegiatan pembelajaran tetapi terkadang sulit dipahami dan dimengerti oleh kebanyakan siswa. Berdasarkan etimologi Elea Tinggih (Suherman, dkk, 2003:16) menyatakan bahwa matematika berarti "ilmu pengetahuan yang diperoleh dengan bernalar". Dalam pernyataan tersebut bukan berarti ilmu yang lain diperoleh tidak melalui penalaran, akan tetapi dalam pembelajaran matematika lebih menekankan aktivitas dalam dunia rasio (penalaran). Sedangkan dalam pembelajaran yang lain lebih menekankan hasil observasi atau eksperimen di samping penalaran.

Salah satu aspek yang dikaji dalam pembelajaran matematika adalah pemecahan masalah. Kurlik dan Rudnik (Hendriana, Rohaeti, dan Sumarno, 2017:44) menyatakan bahwa "pemecahan masalah merupakan proses dimana individu menggunakan pngetahuan, keterampilan, dan pemahaman yang telah diperoleh untuk menyelesaikan masalah pada situasi yang belum dikenalnya". Jadi, pemecahan masalah merupakan proses peserta didik untuk menyelesaikan masalah dalam matematika yang dihadapinya dengan menggunakan pengetahuan, keterampilan dan pemahaman yang dimilikinya.

Pentingnya pemecahan masalah matematis juga dikemukakan oleh Barca (Hendriana, Rohaeti, dan Sumarno, 2017:43) menyatakan bahwa "pemecahan masalah matematis meliputi metode, prosedur, dan strategi yang merupakan proses inti dan utama dalam kurikulum matematika atau merupakan tujuan umum pembelajaran matematika, bahkan sebagai jantungnya matematika".
Berdasarkan observasi dan wawancara pada guru matematika kelas VIII di SMP Islam Abata Malausma, proses pembelajaran yang dilaksanakan pada pembelajaran matematika kurang optimal, hal tersebut disebabkan beberapa alasan yaitu kurangnya penggunaan media yang kreatif dan inovatif untuk menunjang keaktifan dalam pembelajaran matematika, penggunaan model pembelajaran yang kurang tepat, siswa kurang termotivasi untuk belajar matematika karena masih menganggap matematika menakutkan dan juga rumit, dan kegiatan pembelajaran masih didominasi oleh guru.

Melihat kemampuan pemecahan masalah matematika siswa yang dapat dilihat dari hasi belajar masih kurang maksimal. Dari keseluruhan siswa kelas VIII hanya $26 \%$ siswa yang memenuhi kriteria ketuntasan minimum (KKM) dan sisanya yaitu $74 \%$ siswa memiliki nilai di bawah KKM, sedangkan untuk KKM siswa kelas VIII SMP Islam Abata Malausma yaitu $\geq 64$. Siswa yang mendapatkan nilai kurang dari KKM masih banyak.

Pemilihan model pembelajaran yang tepat dalam kegiatan pembelajaran matematika akan mempengaruhi terhadap kemampuan pemecahan masalah matematis siswa. Menurut Suherman, dkk (2003:7) menyatakan bahwa "model pembelajaran adalah sebagai pola interaksi siswa dengan guru di dalam kelas yang menyangkut strategi, pendekatan, metode, dan teknik pembelajaran yang diterapkan dalam pelaksanaan kegiatan belajar mengajar di kelas". Dalam kegiatan pembelajaran, model-model yang sesuai untuk digunakan dalam kegiatan pembelajaran dan dianjurkan dalam kurikulum 2013, yaitu kurikulum yang digunakan pada saat ini adalah model pembelajaran inquiry based learning, discovery learning, project based learning, problem based learning. 
Penulis ingin menerapkan sebuah model pembelajaran yang dapat menjadi alternatif solusi permasalahan yang terjadi. Model pembelajaran tersebut adalah discovery learning. Melalui model ini diharapkan siswa akan mampu mengembangkan kemampuan memecahkan masalah yang dihadapinya dalam pembelajaran matematika yang berkaitan dengan materi Sistem Persamaan Linear Dua Variabel (SPLDV) yang sedang dipelajari oleh siswa SMP. Dalam penelitian ini guru hanya sebagai fasilitator yang berfungsi sebagai jembatan penghubung agar siswa dapat memecahkan permasalahan matematis sendiri. Siswa akan mendapatkan kesempatan untuk menemukan dan mengembangkan ideide baru dalam kegiatan memecahkan permasalahan matematis.

Berdasarkan uraian latar belakang masalah yang dikemukakan sebelumnya, maka dapat kita tentukan rumusan permasalahan penilitian sebagai berikut: (1) Apakah kemampuan pemecahan masalah matematis siswa yang pembelajarannya menggunakan model pembelajaran discovery learning dapat meningkat dengan baik?; (2) Bagaimana aktivitas siswa yang menggunakan model pembelajaran discovery learning discovery learning dalam memecahkan masalah matematis?

\section{KAJIAN LITERATUR DAN PEGEMBANGAN HIPOTESIS}

a. Pengertian Belajar Matematika

Belajar matematika menurut Cobb (Suherman, dkk, 2003:7) menyatakan bahwa "belajar matematika merupakan proses dimana siswa secara aktif mengkonstruksi pengetahuan matematika". Cobb (Suherman, dkk, 2003:7) juga mengatakan dalam bukunya yang lain bahwa "belajar matematika bukan suatu proses pengepakan pengetahuan secara hatihati melainkan tentang mengorganisir

Copyright @20xx, Jurnal Didactical Mathematics aktivitas, dimana kegiatan ini diinterpretasikan secara luas termasuk aktivitas dan berfikir konseptual".

Secara substantif, "belajar matematika adalah proses pemecahan masalah" Confrey, dkk (Suherman, dkk, 2003:7). Menurut pendapat para ahli tersebut penulis dapat menarik kesimpulan bahwa belajar matematika adalah suatu kegiatan yang tersetruktur untuk menyelesaikan dan memecahkan masalah dalam matematika.

\section{b. Tujuan Pembelajaran Matematika}

Menurut Suherman, dkk (2003:55) menyatakan bahwa "tujuan perlunya matematika diajarkan di sekolah adalah bahwa setiap upaya penyusunan kembali atu penyemprnaan kurikulum matematika di sekolah perlu selalu mempertimbangkan kedudukan matematika sebagai salah satu ilmu dasar". Dalam National Research Council tujuan pembelajaran matematika (Shadiq, 2014:8) menyatakan bahwa "di masa kini dan masa yang akan datang, di era komunikasi dan teknologi canggih, dibutuhkan para pekerja cerdas (smarter) daripada pekerja keras (harder). Dibutuhkan para pekerja yang telah disiapkan untuk mampu mencerna ide-ide baru (absorb new ideas), mampu menyesuaikan terhadap perubahan (to adapt to change), mampu menangani ketidak pastian (cope with ambiguity), mampu menemukan keteraturan (perceive patterns), dan mampu memecahkan masalah yang tidak lazim (solve unconventional problems)".

Dari pendapat para ahli dan peraturan pemerintah tersebut penulis dapat menyimpulkan bahwa tujuan pembelajaran matematika adalah sebagai berikut:
a. Mampu memahami permasalahan matematika secara keseluruhan
b. Mampu mengembangkan ilmu pengetahuannya untuk


menyelesaikan

permasalahan

matematika

c. Mampu berpikir kritis dan kreatif dalam menyeesaikan permasalahan matematik

d. Mampu memecahkan permasalahn yang kompleks dengan pola dan struktur yang berbeda

e. Mampu mengkomunikasikan mengenai permasalahan dan caracara pemecahan masalah matematika yang ditemuninya dengan individu atau kelompok lain

f. Mampu menghargai ilmu yang didapatkannya dan mampu menerapkannya dalam kehidupan sehari-hari.

c. Pengertian Pemecahan Masalah Matematis

Menurut Kurlik dan Rudnik (Hendriana, dkk, 2017:44) menyatakan bahwa "pemecahan masalah merupakan proses dimana individu menggunakan pengetahuan, keterampilan, dan pemahaman yang telah diperoleh untuk menyelesaikan masalah pada situasi yang belum dikenalnya". Dari pendapa para ahli penulis menyimpulkan bahwa pemecahan masalah adalah usaha untuk mencari jalan keluar dari suatu masalah dengan menggunakan pengetahun, keterampilan, dan ilmu yang telah didapat sebelumnya.

Sedangkan pemecahan masalah matematika menurut Lencher (Hartono, 2013:3) menyatakan bahwa "pemecahan masalah matematika sebagai proses menerapkan pengetahuan matematika yang telah diperoleh sebelumnya ke dalam situasi baru yang belum dikenal". Sejalan dengan pendapat Turmudi (Jatisunda,2017:4) mengemukakan bahwa "problem solving atau pemecahan masalah dalam matematika melibatkan metode dan cara penyelesaian yang tidak setandar dan tidak diketahui terlebih dahulu. Sehingga pemecahan merupakan suatu proses kegiatan yang lebih mengutamakan prosedur-prosedur yang harus ditempuh dan langkahlangkah strategi yang harus ditempuh siswa dalam menyelesaikan masalah, dan pada akhirnya siswa mengerti tujuan utama bukan hanya menemukan jawaban dari soal tetapi lebih dari itu yaitu terdapat proses yang harus dijalankan".

Dengan demikian penulis menyimpulkan bahwa pemecahan masalah matematika adalah usaha untuk menyelesaikan permasalahan matematika dengan menggunakan pengetahuan yang telah didapat sebelumnya.

\section{d. Indikator Pemecahan Masalah Matematis}

Pemecahan yang dilakukan oleh siswa dalam proses pembelajaran memiliki indikator tersendiri agar dapat digolongkan dengan mudah mana siswa yang sudah mampu memecahkan masalah dan siswa yang belum mampu memecahkan masalah. Indikator dalam pemecahan masalah matematika menurut Badan Standar Nasional Pendidikan (BNSP) adalah sebagai berikut:

1) Menunjukkan pemahaman masalah

2) Mengorganisasi data dan menulis informasi yang relevan dalam pemecahan masalah

3) Menyajikan masalah secara matematika dalam berbagai bentuk

4) Memilih pendekatan dan metode pemecahan masalah secara tepat

5) Mengembangkan strategi pemecahan masalah

6) Membuat dan menafsirkan model matematika dari suatu masalah

7) Menyelesaikan masalah matematika yang tidak rutin.

Hal ini seejalan dengan George

Polya (Hartono, 2013:3) mengemukakan terdapat empat tahapan penting yang harus ditempuh siswa dalam memecahkan masalah. Yakni, memahami masalah, menyusun rencana pemecahan, melaksanakan 
rencana pemecahan, dan memeriksa kembali".

Berdasarkan pendapat ahli tersebut maka penulis dapat menarik kesimpulan bahwa pemecahan masalah memiliki langkah sebagai berikut: (1) memahami masalah, (2) merumuskan masalah, (3) mencari sumber untuk memecahkan masalah , (4) memecahkan masalah, (5) menarik kesimpulan.

\section{e. Pengertiam Model Pembelajaran Discovery Learning}

Model pembelajaran discovery learning (penemuan) merupakan model pembelajaran yang dikembangkan berdasarkan kontruktivisme. Menurut Sund (Roestiyah, 2008:20) menyatakan bahwa "discovery adalah proses mental dimana siswa mampu mengasimilasikan sesuatu konsep atau prinsip. Yang dimaksud dengan proses mental tersebuat antara lain ialah : mengamati, mencerna, mengerti, menggolong-golongkan, membuat dugaan, menjelaskan, mengukur, membuat kesimpulan, dan sebagainya".

Lestari (2015:64) mengemukakan terdapat empat tahapan dalam discovery learning:

1. Data collection (kegiatan mengumpulkan data/informasi).

2. Data processing (kegiatan pengolahan data/informasi).

3. Verification (verifikasi data).

4. Generalization (membuat kesimpulan berdasarkan hasil dari kegiatan yang telah dilakukan).

\section{f. Kelebihan Model Pembelajaran Discovery Learning}

Pemilihan model pembelajaran yang tepat akan mempengaruhi hasil dari penelitian yang dilakukan, dalam penelitian ini peneliti memilih model pembelajaran discovery learning karena dianggap tepat dan akan efektif digunakan dalam kegiatan pembelajaran matematika. Menurut Roestiyah (2008:20-21) mengemukakan beberapa kelebian model pembelajaran discovery learning, yaitu sebagai berikut:

1) Teknik ini mampu membantu siswa untuk mengembangkan; memperbanyak kesiapan; serta penguasaan keterampilan dalam proses kognitif/ atau pengenalan siswa.

2) Siswa memperoleh pengetahuan yang bersifat sangat pribadi/ individual sehingga dapat kokoh/ mendalam dalam jiwa siswa tersebut.

3) Dapat membangkitkan kegairahan belajar para siswa.

4) Teknik ini mampu memberikan kesempatan kepada siswa unuk berkembang dan maju sesui dengan kemampuannya masing-masing.

5) Mampu mengerahkan cara siswa belajar, sehingga lebih memiliki motivasi yang kuat untuk belajar lebih giat.

6) Membantu siswa untuk memperkuat dalam menambah kepercayaan pada diri sendiri dengan proses penemuan sendiri.

7) Strategi ini berpusat pada siswa tidak pada guru. Guru hanya sebagai teman belajar saja; membentu bila diperlukan.

Berdasarkan pemaparan pemaparan para ahli di atas peneliti menarik kesimpulan mengenai kelebihan dari model pembelajaran discovery learning, sebagai berikut:

a. Meningkatkan kemampuan kognitif siswa,

b. Siswa lebih aktif dan kreatif dalam berfikir,

c. Mendorong siswa lebih aktif dalam kegiatan pembelajaran, 
d. Meningkatkan kemampuan siswa dalam memecahkan masalah,

e. Mampu menentukan hipotesis,

f. Mampu bekerja sama dalam menyelesaikan permasalahan,

g. Mampu menarik kesimpulan dari berbagai sumber yang telah dikumpulkan.

\section{Hipotesis}

penggunaan model pembelajaran discovery learning dapat meningkatkan kemampuan pemecahan masalah matematis siswa kelas VIII SMP.

\section{METODE PENELITIAN}

Metode penelitian eksperimen memiliki bermacam-macam jenis desain. Desain pada penelitian ini menggunakan The Nonequivalent Pretest-Posttest Control Group Design. Pada desain ini sampel yang diambil, baik kelompok eksperimen maupun klompok kontrol tidak dipilih secara acak murni (random). Pengacakan yang dilakukan pada desain ini yaitu acak kelas, dengan sampel memiliki karakteristik yang homogen atau tidak ada kelas unggulan. Sebelum dilakukan penelitian, kedua kelompok diberikan pretes (tes awal) untuk mengetahui keadaan awal. Selama penelitian berlangsung, kelompok pertama diberikan perlakuan $(X)$ dan kelompok kedua tidak diberikan perlakuan. kelompok yang diberikan perlakuan dijadikan kelompok eksperimen dan kelompok yang tidak diberikan perlakuan dijadikan kelompok control. Dan selanjutya di akhir penelitian, kedua kelompok diberi postes (tes akhir) untuk melihat bagaimana hasilnya. Lestari dan Yudhanegara (2015:138).

\begin{tabular}{|ccc|}
\hline & $\mathrm{O}$ & $\mathrm{O}$ \\
$\mathrm{O}$ & $\mathrm{O}$ \\
\hline
\end{tabular}

Keterangan :

$X=$ perlakuan/treatment yang diberikan (variable independen)
$\mathrm{O}=$ pretes/postes (variabel dependen yang diobservasi)

\section{A. Populasi dan Sampel}

Populasi dalam penelitian ini adalah seluruh siswa kelas VIII SMP Islam Abata Malausma, Kecamatan Malausma Kabupaten Majalengka tahun ajaran 2018/2019 yang terdiri dari 120 siswa yang terbagi dalam 5 kelas. Sampel diambil pada kelas VIII A sebagai kelas eksperimen dab VIII B sebagai kelas Kontrol di SMP lalsam Abata Malausma, karena kelas VIII sudah dianggap mampu beradaptasi dengan pembelajaran yang menggunakan model pembelajaran baru yang berbeda dengan sebelumnya dan tidak akan mengganggu program sekolah untuk melakukan ujian akhir sekolah.

\section{B. Teknik Pengumpulan Data}

Pengumpulan data dilakuk pada setiap kegiatan penelitian dan situasi yang berkaitan dengan kegiatan penelitian menggunakan instrument berupa soal pretes, postes, dan lembar observasi. Teknik pengumpulan data secara jelas di rincikan dalam table di bawah ini:

Tabel 1. Teknik Pengumpulan Data

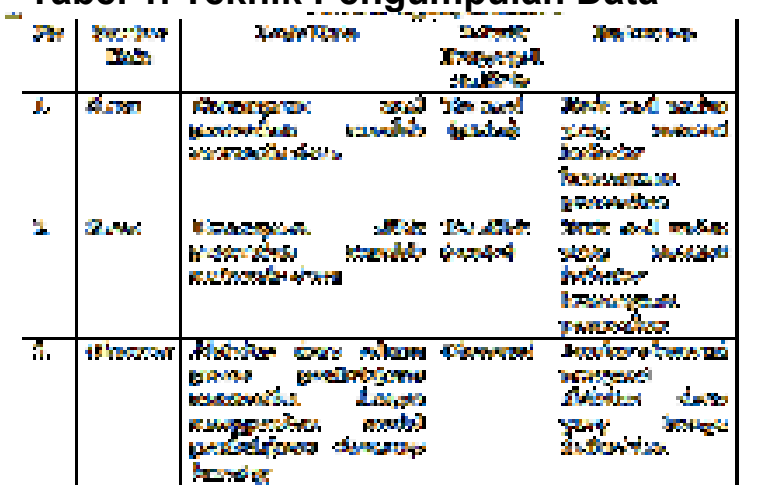

\section{HASIL DAN PEMBAHASAN}

\section{a. Uji Data N-Gain}

Uji data $N$-gain dilakukan untuk mengetahui peningkatan kemampuan siswa, data ini juga memeberikan informasi mengenai pencapaian kemampuan siswa. Hasil analisis data $\mathrm{N}$-gain dapat dilihat pada tabel 2. 
Tabel 2. Data $\mathbf{N}$-gain Kelas Kontrol dan Eksperimen

\begin{tabular}{|c|c|c|c|c|}
\hline 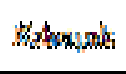 & 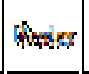 & hever & 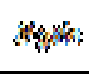 & 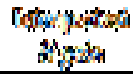 \\
\hline stoplestea & spthe & 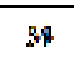 & Egs & discon \\
\hline rand & sdt. & 政然 & is & Dolowa \\
\hline
\end{tabular}

Data tabel di atas menunjukkan bahwa a nilai $N$-gain yang diperoleh adalah 0,39 berkategori sedang. Sehingga dapat disimpulkan bahwa peningkatan kemampuan pemecahan masalah matematis siswa meningkat dengan kategori yang sama yaitu sedang baik pada kelompok kontrol, begitupun kelompok eksperimen.

\section{1) Uji Normalitas Data N-Gain}

Pengujian normalitas data $n$-gain menggunakan uji statistic Shapiro-Wilk dalam soptware SPSS 16.0 for windows.

Rumusan hipotesis:

$\mathrm{H}_{\mathrm{o}}$ : Data berdistribusi normal

$\mathrm{H}_{1}$ : Data tidak berdistribusi normal

Dengan menggunakan taraf signifikansi $a=0,05$ maka kriteria pengujianya yaitu jika $\mathrm{Sig}>\mathrm{a}$ maka $\mathrm{H}_{\mathrm{o}}$ diterima, sedangkan jika Sig < a maka $\mathrm{H}_{\mathrm{o}}$ ditolak. Hasil uji statistik normalias pada kelas eksperimen dan kontrol dapat dilihat pada table 3 .

Tabel 3. Uji Normalitas Nilai $\mathbf{N}$-Gain Kelas Eksperimen dan Kelas Kontrol

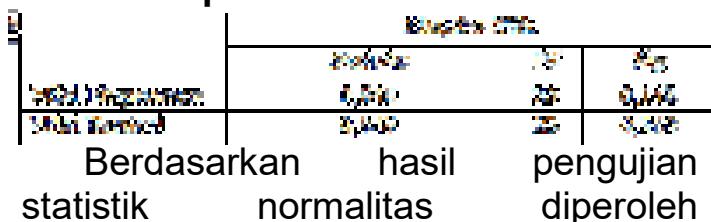
signifikansi uji Shapiro-Wilk data $n$-gain pada kelas eksperimen dan kelas kontrol berdistribusi normal.

\section{2) Uji Homogenitas Data N-Gain}

Uji homogenitas varians dari data $n$ gain dengan menggunakan uji Levene pada SPSS 16.0 for windows dilakukan untuk mengetahui variansi dari data bersistribusi normal atau tidak. Hipotesis yang diuji yaitu:

$\mathrm{H}_{\mathrm{o}}=$ Kedua varians homogen

Copyright @20xx, Jurnal Didactical Mathematics
$\mathrm{H}_{1}=$ Kedua varians tidak homogen

Taraf signifikansi $a=0,05$ dengan kriteria jika nilai signifikansi > a, maka $\mathrm{H}_{\mathrm{o}}$ diterima, dan jika nilai signifikansi < a maka $\mathrm{H}_{\mathrm{o}}$ ditolak . Hasil uji homogenitas pada kelas eksperimen dan kontrol dapat dilihat pada table 4

Tabel 4. Hasil Uji Homogenitas $\mathbf{N}$ Gain Kelas Eksperimen dan kelas Kontrol

\begin{tabular}{|c|c|c|c|}
\hline $\begin{array}{c}\text { Levene } \\
\text { Statistic }\end{array}$ & df1 & df2 & Sig \\
\hline 0,123 & 1 & 46 & 0,728 \\
\hline
\end{tabular}

Kemampuan pemecahan masalah matematis siswa pada kelas eksperimen dan kelas kontrol dari table di atas diperoleh nilai signifikansinya 0,728 . Nilai signifikansi pada hasil uji homogenitas kelas eksperimen dan kontrol lebih besar dari atau Sig > a dengan $\mathrm{a}=0,05$, maka $\mathrm{H}_{\mathrm{o}}$ diterima dan tidak ada alasan untuk dapat menolak $\mathrm{H}_{\mathrm{o}}$. Dari data tersebut makan dapat disimpulkan bahawa variansi data dari sampel yang dianalisis adalah homgen.

\section{3) Uji Kesamaan Rata-rata N-Gain}

Uji kesamaan rata-rata (uji t' Equal variances not assumed) karena kedua varians tidak homogen. Hal ini dilakukan untuk mengetahui apakah terdapat perbedaan antara kemampuan akhir pemecahan masalah matematis siswa kelas eksperimen dan kemampuan akhir pemecahan masalah matematis siswa kelas kontrol. Hipotesisnya sebagai berikut:

Hipotesis:

$\mathrm{H}_{\mathrm{o}}$ : Tidak terdapat perbedaan rata-rata antara kemampuan pemecahan masalah matematis siswa kelas eksperimen dengan rata-rata kelas kontrol

$\mathrm{H}_{1}$ : Terdapat perbedaan rata-rata antara kemampuan pemecahan masalah matematis siswa kelas eksperimen dengan rata-rata kelas kontrol

Kriteria pengujian $H_{0}$ diterima jika nilai signifikansi dari pengolahan data > a, sedangkan jika nilai signifikansi $<$ a mka $\mathrm{H}_{\mathrm{o}}$ ditolak dengan $\mathrm{a}=0,05$. Hasil 
uji kesamaan rata-rata n-gain kemempuan pemecahan masalah matematis siswa kelas eksperimen dan kelas kontrol dapat dilihat pada tabel 5

. Tabel 5. Uji Kesamaan Rata-rata N-Gain

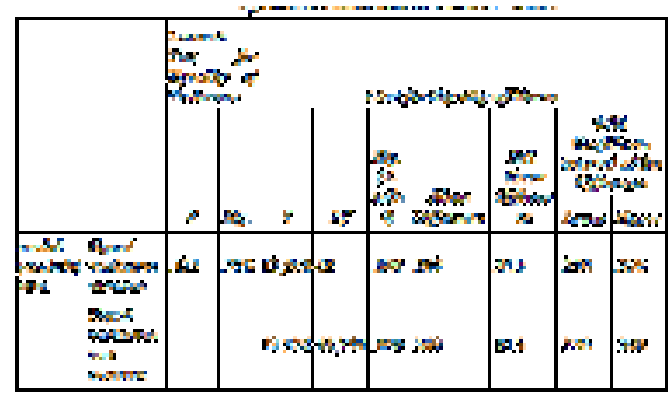

Berdasarkan tabel di atas diperoleh nilai signifikansi untuk Levene's Test for Equality of Variances menyatakan kedua varians homogen, maka nilai $t_{\text {hitung }}$ yang digunakan adalah yang berdasarkan uji t, yaitu sebesar 17,388 dengan signifikansi (2-tailed) sbesar 0,000 .

Nilai signifikansi (2-tailed) yang diperoleh lebih kecil dari $a=0,05$, mka $\mathrm{H}_{\mathrm{o}}$ ditolak. Artinya pada taraf kepercayaan $95 \%$ dapat disimpulkan bahwa terdapat perbedaan rata-rata antara kemampuan pemecahan masalah matematis siswa kelas eksperimen dengan rata-rata kelas kontrol.

\section{b. Data Lembar Observasi Siswa}

Kegiatan observasi dalam penelitian dilakukan untuk menunjang dalam mengetahui kemampuan pemecahan masalah matematis siswa di dalam kelas secara lebih terperinci. Dengan kriteria penskoran lebar observasi siswa sebagai berikut: Data hasil observasi pada kelas eksperimen dan kelas kontrol dapat di lihat pada tabel 6 .

Tabel 6. Observasi Kelas Eksperimen dan Kelas Kontrol

\begin{tabular}{|c|c|c|c|c|c|c|}
\hline & \multicolumn{5}{|c|}{ 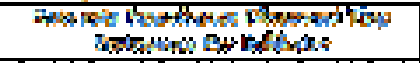 } & \multirow[t]{2}{*}{$\frac{178}{x y 3}$} \\
\hline & 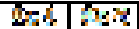 & 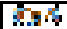 & 62 & 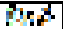 & दृध & \\
\hline Exe & $\sin$ & सुह & \$. & 5,38 & $\pi$ & ats \\
\hline & zis & & Inst & & $\overline{7}$ & \\
\hline
\end{tabular}

Dari tabel di atas diperoleh hasil observasi dengan rata-rata skor kelas eksperimen untuk pertemuan pertama adalah 1,76 (sangat kurang), pertemuan kedua 2,44 (kurang), pertemuan ketiga 2,88(kurang), pertemuan keempat 3,2 (cukup), pertemuan kelima 3,52(cukup) dan pertemuan keenam 4 (baik). Untuk kelas kontrol mendapatkan rata-rata pada pertemuan pertama 1,64 (sangat kurang), pertemuan kedua 2,22 (kurang), pertemuan ketiga 2,48 (kurang), pertemuan keempat 2,74 (kurang), pertemuan kelima 2,91 (kurang), dan pertemuan keenam 3,08 (cukup). Dilihat dari hasil rata-rata yang didapat tiap pertemuan untuk kelas eksperimen mengalami peningkatan, dan di pertemuan terakhir mendapatkan rata-rata dengan indicator yang baik. Sedangkan kelas kontrol kurang mengalami peningkatan dan dipertemuan terakhir hanya mendapatkan nilai dengan indikator yang cukup.

\section{B. Pembahasan}

Pelaksanaan penelitian ini diawali dengan melakukan pengamatan pada kelas VIII SMP Islam Abata Malausma. Berdasarkan pengamatan yang dilakukan menunjukan bahwa kegiatan pembelajaran yang dilaksanakan belum mampu meningkatkan kemampuan pemecahan masalah. Seperti halnya siswa kurang bersemangat dalam kegiatan pembelajaran matematika dikarenakan berbagai alasa. Siswa menganggap bahwa mata pelajaran matematika merupakan mata pelajaran yang menakutkan karena penuh dengan rumus dan berbagai macam alasan, guru belum menerapkan model pembelajaran lain dari biasanya digunakan, Selain itu kegiatan pembelajaran masih terpusat pada guru. Hal ini yang memicu siswa terkadang kurang mampu dalam memecahkan permasalahn matematis. Pendapat penulis tersebut juga di dukung oleh pendapat Herman (2010:1) menyatakan bahwa "salah satu penyebab rendahnya penguasaan 
matematika siswa adalah guru tidak member kesempatan yang cukup kepada siswa untuk membangun sendiri kemampuanya, matematika dipelajari oleh kebanyakan siswa secara langsung dalam bentuk yang sudah jadi (formal), karena matematika dipandang oleh kebanyakan guru sebagai proses yang prosedural dan mekanistik".

Beberapa permasalahan tersebut yang mendorong penulis untuk melakukan penelitian di kelas VIII SMP Islam Abata Malausma pada kelas VIII A dan VIII B. Kelas VIIIA sebagai kelas eksperimen dan kelas VIIIB sebagai kelas kontrol. Pada penelitian ini penulis menggunakan model pembelajaran Discovery Learning untuk meningkatkan kemampuan pemecahan masalah matematis di SMP Islam Abata Malausma. Penelitian ini dilaksanakan dari bulan Agustus sanpai bulan September 2018, pada pembelajaran Sistem Persamaan Linear Dua Variabel (SPLDV).

Kegiatan penelitian diawali dengan memberikan pretes pada kelas VIII A sebagai kelas eksperimen menggunakan soal yang sama diberikan pretes kepada pada kelas VIII B sebagai kelas kontrol, pada awal kegiatan pemberian tes kemampuan pemecahan masalah siswa, keduanya memiliki kemampuan pemecahan masalah yang sangat minim dengan rata-rata kemampuan kedua kelas tersebut sama yaitu 5,44 dari nilai maksimal 80 untuk kelas eksperimen dan 5,43 dari nilai maksimal 80 untuk kelas kontrol. Artinya pada awal kegiatan penelitian ini penulis menggunakan kelas yang memiliki kemampuan awal yang sama.

Selanjutnya penulis memberikan perlakukan kepada kelas eksperimen dengan memberikan materi menggunakan model pembelajaran Discovery Learning sedangkan pada kelas kontrol menggunakan model pembelajaran konfensional. Penulis juga melakukan kegiatan penilaian kemampuan pemecahan masalah siswa baik itu pada kelas eksperimen maupun kelas kontrol.

Pada awal kegiatan pembelajaran di kelas eksperimen dengan menggunakan model pembelajaran Discovery Learning rata-rata siswa masih kurang trampil dalam mengikuti kegiatan pemecahan karena sama sekali tidak dapat menerapkan konsep/prinsip dan starategi pemecahan masalah yang relevan yang berkaitan dengan materi dikarenakan beberapa faktor, yaitu belum terbiasa dengan langkah pemecahan menggunakan model Discovery Learning, siswa masih terbiasa dengan pembelajaran yang terpusat pada guru, dan masih terbiasa dengan model pembelajaran yang lama. Sedangkan pada kelas kontrol dengan materi yang sama siswa mengikuti pembelajaran seperti biasanya dengan menggunakan model pembelajaran konfensional dan ratarata siswa masih kurang trampil dalam mengikuti kegiatan pemecahan karena sama sekali tidak dapat menerapkan konsep/prinsip dan starategi pemecahan masalah yang relevan yang berkaitan dengan materi, hal itu dikarenakan siswa belum memahami apa yang harus dilakukan untuk memecahkan masalah matematis tersebut.

Pertemuan berikutnya rata-rata siswa kelas eksperimen sudah cukup trampil dalam memecahkan masalah karena mampu menerapkan konsep/prinsip dan strategi pemecahan masalah yang relevan yang berkaitan dengan materi namun membutuhkan waktu lebih lama dalam melakukan langkah pemecahan masalah menggunakan model pembelaja Discovery Learning. Pada kelas kontrol siswa belajar seperti biasanya dengan menggunakan model pembelajaran konpensional tetapi rata-rata siswa masih kurang terampil karena sama 
sekali tidak dapat menerapkan konsep/prinsip dan strategi pemecahan masalah yang relevan yang berkaitan dengan materi.

Pada pertemuan berikutnya ratarata siswa kelas eksperimen sudah baik dalam melakukan langkah pemecahan karena mampu menerapkan konsep/prinsip dan strategi pemecahan masalah yang relevan yang berkaitan dengan materi dalam waktu normal dengan menggunakan model pembelajaran Discovery Learning, sedangkan pada kelas kontrol kebanyakan rata-rata siswa cukup trampil dalm melakukan langkah pemecahan karena mampu menerapkan konsep/perinsip dan strategi pemecahan masalah yang relevan yang berkaitan dengan materi.

Kegiatan di akhir pembelajaran pada siswa kelas eksperimen dengan menggunakan model pembelajaran Discovery Learning siswa memiliki rata-rata kemampuan yang baik dalam melakukan langkah pemecahan karena mampu menerapkan konsep/prinsip dan strategi pemecahan masalah yang relevan yang berkaitan dengan materi dalam waktu normal. Sedangkan pada siswa kelas eksperimen dengan menggunakan model pembelajaran konvensional rata-rata kebanyakan siswa memiliki kemampuan cukup trampil dalm melakukan langkah pemecahan karena mampu menerapkan konsep/perinsip dan strategi pemecahan masalah yang relevan yang berkaitan dengan materi.

Ternyata setelah dilakukan pemeriksaan dan perhitungan pada kelas ekperimen yang mendapatkan perlakuan menggunakan model pembelajaran Discovery learning memiliki kemampuan pemecahan masalah matematis lebih baik daripada kelas kontrol yang mendapatkan perlakuan dengan menggunakan model pembelajaran konfensional. Hal ini dibuktikan dengan rata-rata nilai akhir kelas eksperimen adalah 4 dari nilai maksimal 5 yang berarti memiliki kemampuan yang baik, sedangkan rata-rata nilai akhir kelas kontrol adalah 3 dari 5 yang berarti memiliki kemampuan yang cukup.

Kriteria dari kemampuan pemecahan masalah yang penulis harapka dari kelas eksperimen dengan menggunakan pembelajaran Discovery Learning dalam penelitian ini adalah kemampuan pemecahan masalah dengan nilai 5 yang berarti sangat baik tetapi pada kenyataanya kemampuan siswa kelas eksperimen hanya sampai pada kemampuan pemecahan masalah yang baik dengan nilai 4 . Hal tersbut dikarenakan beberapa faktor diantaranya. Yaitu, masih kurangnya buku sumber yang memang dibutuhkan dalam kegiatan pembelajaran penemuan ini, masih ada siswa yang belum memahami dalam mencari sumber dengan menggunakan internet, dan tidak semua siswa memiliki kemampuan pemecahan masalah dengan menemukan sendiri.

Hasil observasi kegiatan siswa dalam melakukan pemecahan masalah dikelas tersebut dapat disimpulkan bahwa kemampuan pemecahan masalh matematis siswa yang menggunakan model pembelajaran Discovery Learning lebih baik dibandingkan dengan kemampuan pemecahan masalah matematis siswa yang menggunakan model pembelajaran konfensional. Hal ini didukung dengan hasil uji postes yang dilakukan pada kedua kelas tersebut, nilai rata-rata kelas yang menggunakan model pembelajaran Discovery Learning yaitu 54 dari nilai maksimal 80 , dan nilai rata-rata kelas yang menggunakan model pembelajaran konfensional yaitu 34 dari nilai maksimal 80.

Selama pelaksanaan penelitian di lapangan, penulis telah mengumpulkan data-data penelitian yang diperoleh dari hasil observasi atau pengamatan, dan tes. Pada saat penelitian, ada beberapa 
pokok-pokok temuan penelitian antara lain:

1. Model pembelajaran Discovery Learning mampu meningkatkan kemampuan pemecahan masalah matematis siswa.

2. Pemberian penghargaan kepada siswa ketika pembelajaran mampu meningkatkan motivasi siswa untuk belajar matematika.

3. Penggunaan model pembelajaran Discovery Learning mampu mendorong siswa untuk dapat memecahkan permasalahan matematis dengan menemukan sendiri penyelesaiannya.

\section{KESIMPULAN}

Hasil Penelitian mengenai

Penggunaan Model Pembelajaran Discovery Learning Untuk Meningkatkan Kemampuan Pemecahan Masalah Matematis Pada Siswa SMP di SMP Islam Abata Malausma dapat disimpulkan sebagai berikut:

1. Penggunaan model pembelajaran discovery learning dapat meningkatkan kemampuan pemecahan masalah matematis siswa SMP kelas VIII dengan sangat baik. Hal ini dibuktikan dengan nilai rata-rata di akhir pembelajaran sebesar 54 dari skor maksimal 80 yang pada awalnya hanya memiliki rata-rata 5,44 dari skor maksimal 80 .

2. Aktivitas siswa ketika pembelajaran menggunakan model discovery learning dalam memecahkan masalah matematika sebesar $80 \%$ pada kategori baik . Hal ini dibuktikan dengan peningkatan aktivitas siswa ketika pembelajaran sebesar 4 dari nilai maksimal 5 dan hal itu termasuk dalam kategori baik.

\section{REFERENSI}

Anwar, Muhammad. (2015). Filsafat Pendidikan. Jakarta: Kencana Prenadamedia Group

Copyright @20xx, Jurnal Didactical Mathematics
Arikunto, S. dan Supardi. (2010). Penelitian Tindakan Kelas. Jakarta: Bumi Aksara

Badan Standar Nasional Pendidikan (BSNP), Loc. Cit.

Departemen Pendidikan Nasional Republik Indonesia. (2003). Undang-Undang Republik Indonesia Nomor 20 Tahun 2003 Tentang Sistem Pendidikan Nasional,. Jakarta: Biro Hukum dan Organisasi Sekertariat Jendral Departemen Pendidikan Nasional.

Epi M. (2016). Penerapan Model Pembelajaran Problem Based Learning Untuk Meningkatkan Kemampuan Pemecahan Masalah Siswa Pada Mata Pelajaran IPS di Kelas IV [skripsi]. Majalengka: Universitas Majalengka.

Hamzah, Ali. (2014). Evaluasi Pembelajaran Matematika. Jakarta: PT RAJAGRAFINDO PERSADA

Hendriana, Heris. Dkk. (2017). Hard Skills dan Soft Skills Matematik Siswa. Bandung: PT Rafika Aditama

Hartono, Yusuf. (2013). Matematika Strategi Pemecahan Masalah. Yogyakarta: Graha IImu

Jatisunda, M. Gilar. "Hubungan SelfEfficacy Siswa SMP dengan Kemampuan Pemecahan Masalah Matematis." Theorems 1.2 (2017).

Kurniasih dan Sani (2014). Model Discovery Learning.Diakses pada tanggal 3 Maret 2016. ("Tutoring and APA,"n.d.) diambil dari: http://digilib.unila.ac.id/10116/15/ BAB\%20II.pdf

Lestari, Eka Kurnia. Yudhanegara, R.M. (2015). Penelitian Pendidikan Matematika. Bandung: PT. Refika Aditama

Muhamad, N. (2017). Pengaruh Metode Discovery Learning untuk Meningkatkan Representasi Matematis dan Percaya Diri 
Siswa. Jurnal Pendidikan UNIGA, 10(1), 9-22.

Marantika, Aryani.Handayani, Tutut. Dumeva Putri, Agustiany. (2015). Pengaruh Metode Discovery Learning Terhadap Kemampuan Pemecahan Masalah Matematika Siswa Pada Pembelajaran Matematika Di SMP Pelita Palembang. Jurnal Pendidikan Matematika. Vol. 1,No. 2. Diambil dari:

http://jurnal.radenfatah.ac.id/index .php/jpmrafa/article/view/1229+\&c $\mathrm{d}=1 \& \mathrm{hl}=\mathrm{id} \& \mathrm{ct}=\mathrm{clnk} \& \mathrm{gl}=\mathrm{id}$

Peraturan Menteri Pendidikan Dan Kebudayaan Republik Indonesia Nomor 58 Tahun 2014 Tentang Kurikulum $2013 \quad$ Sekolah Menengah Pertama/Madrasah Tsanawiyah. Diambil dari: https://mintotulus.files.wordpress. com/.../permendikbud-no-58tahun-2014-tentang-kurikulumsmp-mts

Peraturan Menteri Pendidikan Dan Kebudayaan Republik Indonesia Nomor 104 Tahun 2014 Tentang Penilaian Hasil Belajar Oleh Pendidik Pada Pendidikan Dasar Dan Pendidikan Menengah. Diambil dari: pgsd.uad.ac.id/wpcontent/uploads/lampiranpermendikbud-no-103-tahun2014.pdf

Paparan Wakil Menteri Pendidikan Dan Kebudayaan R.I Bidang Pendidikan. Mengenai Konsep Dan Implementasi Kurikulum 2013 Tahun 2014 Kementrian Pendidikan Dan Kebudayaan. Diambil dari: https://kemdikbud.go.id/kemdikbu d/dokumen/Paparan/Paparan\%20 Wamendik.pdf

Roestiyah, N.K, (2008), Strategi Belajar Mengajar, Jakarta: PT. RINEKA CIPTA

Rusdiana, A. (2015). Pengelolaan Pendidikan. Bandung: CV PUSTAKA SETIA
Sibaweh, Imam, Nurudin, Diding.. (2015). Pengelolaan Pendidikan. Jakarta: PT. RAJAGRAFINDO PERSADA

Sri Wulandari Danoebroto. (2011). Faktor-Faktor Yang Berpengaruh Terhadap Kemampuan Siswa Memecahkan Masalah Matematika. Diambil dari: http://p4tkmatematika.org/file/Kar ya\%20WI14\%20s.d\%2016\%200k t\%202011/Faktor\%20dalam\%20P roblem $\% 20$ Solving.pdf8

Shadiq, Fadjar. (2014). Pembelajaran Matematika. Yogyakarta: Graha IImu

Sugiono. (2015). Metode Penelitian Pendidikan. Bandung

ALFABETA

Suherman, Erman, dkk. (2003). Strategi Pembelajaran Matematika Kontemporer. Bandung: Common Textbook

Van De Walle, John A.(2006). Matematika sekolah dasar dan menengah. Jakarta: Erlangga

Wijaya, Ariyadi. (2012). Pendidikan Matematika Realistik. Yogyakarta: Graha IIm

Widiadnyana, I. Wayan, I. Wayan Sadia, dan I, Wayan Suastra. "Pengaruh model discovery learning terhadap pemahaman konsep IPA dan sikap ilmiah siswa SMP." Jurnal Pendidikan dan Pembelajaran IPA Indonesia 4.1 (2014).(3.1344.1) 